From data obtained by ligaturing experiments ${ }^{\mathbf{1 5}}$ it seems that, during the last larval instar, prothoracic glands are needed until the second peak of $\beta$-ecdysone in accordance with their role in ecdysone biosynthesis? The two peaks of $\beta$-ecdysone reported here agree well with the existence of two periods of prothoracicotropic hormone (PTTH) release by the brain ${ }^{16}$, that correspond to the transition to wandering stage and moult to pupa. This problem will be discussed in more detail elsewhere, and we shall consider here the case of pupae only.

We have previously reported that there was a good correlation between $\beta$-ecdysone levels and ribosomal RNA synthesis in pupal wings ${ }^{13}$. In vitro experiments using Galleria ${ }^{17}$ or Drosophila ${ }^{18}$ imaginal discs showed that $\beta$-ecdysone enhanced both precursor uptake and net RNA synthesis, while $\alpha$-ecdysone would perhaps increase precursor uptake only ${ }^{17}$. In our experiments, whole wing RNA decreased and precursor incorporation was reduced during the first pupal peak of $\alpha$-ecdysone. All these results argue against a possible stimulation of ribosomal (stable) RNA synthesis by $\alpha$-ecdysone.

The control of DNA synthesis seems more complex, because the published data are not in good agreement ${ }^{10,12}$ It is reported that in the pupa ${ }^{3} \mathrm{H}$-Thymidine incorporations is much lowered in the presence of high levels of $\beta$-ecdysone, according to in vitro data for Gallevia ${ }^{10}$ and in vivo experiments with Saturniid pupae, that showed an inhibition of wing scales development by injections of high doses of various ecdysones ${ }^{19}$, as with inhibitors of DNA syntheses ${ }^{20,21}$. High doses of $\alpha$-ecdysone are not reported to have such an inhibitory effect. Our experiments do not show a close relationship between $\alpha$-ecdysone and DNA syntheses, as would be expected from experiments using Galleria wing discs ${ }^{10}$ and Drosophila celllines ${ }^{22}$. In Drosophila imaginal leg discs cultured in vitro with $\alpha$-ecdysone, mitoses do occur, as sockets and bristles differentiate ${ }^{23}$. In the case of Pieris, polyploidization in trichogen cells begins during the first peak of $\alpha$ ecdysone. Thus it seems possible that both low levels of $\beta$-ecdysone - as recently suggested with Galleria ${ }^{24}$ and $\alpha$-ecdysone are able to stimulate DNA synthesis. The problems could differ according to animal species", organs or developmental stages. Further experiments seem to be needed for a better understanding, because there is actually no evidence for the absence of $\alpha \rightarrow \beta$ conversion in culture experiments using $\alpha$-ecdysone.

Some other data are in favour of a specific role of $\alpha$-ecdysone. At low doses, it is capable of reinforcing $\beta$ ecdysone effects on cuticle synthesis ${ }^{25}$, that in Pieris pharate adult occurs after the $(\alpha+\beta)$ peak. Moreover, testes of diapausing Samia respond to low $(0.1 \mu \mathrm{g} / \mathrm{ml})$ doses of $\alpha$-ecdysone. In Chironomus salivary gland cells in vitro, the two hormones induce different puffs ${ }^{26} . \alpha-$
Ecdysone-binding-proteins ('receptors') have been described in Drosophila salivary glands ${ }^{27}$.

For all these reasons, we think that both $\alpha$-ecdysone and $\beta$-ecdysone are true hormones, evoking specific responses in target organs. However, only $\beta$-ecdysone have noticeable effects at low doses on some processes as rRNA or cuticle synthesis. The existence of other active hormones ${ }^{28}$ and the possible need of cofactors in ecdysone action $\mathbf{2 4 , 2 9 , 3 0}$ render such studies even more diffciult.

Résumé, Les taux d' $\alpha$ - et de $\beta$-ecdysone ont été déterminés dans l'hémolymphe de Pievis brassicae au cours du dernier stade larvaire et de la métamorphose. Parallelement, les taux de synthèse d'ADN, d'ARN et de protéines ont été mesurés dans les ébauches alaires. La comparaison de ces données a été discutée en fonction du mode d'action possible des deux hormones.

R. Lafont ${ }^{31}$, B. Mauchamp, J. L. Pennetier, P. Tarroux, L. De Hys and J. P. Delbecgue

Ecole Normale Supérieure, Laboratoive de Zoologie, 46, rue d'Ulm, F-75230 Paris Cédex 05 (France), SEITA, Service de Recherche.

F-75340 Paris Cédex 07 (France), and

Faculté des Sciences, Laboratoive de Zoologie,

F-21000 Dijon (France), 12 May 1975.

${ }^{15}$ R. Lafont, B. Mauchamp, G. Boulay and P. Tarroux, Comp. Biochem. Physiol. 51 B, 439 (1975).

$16 \mathrm{~J}$. W. Truman and L. M. Riddiford, J. exp. Biol. 60, 371 (1974). $17 \mathrm{G}$. Bergtom and H. OBERLANDER, J. Insect Physiol. 21, 39 (1975). 18 R. Raikow and J. W. Fristrom, J. Insect Physiol. 17, 1599 (1971).

to C. M. Williams, Biol. Bull. 134, 344 (1968).

20 A. Krishnakumaran, S. J. Berry, H. Oberlander and H. A. Schneiderman, J. Insect Physiol. 13, 1 (1967).

21 R. Lafont, C. r. Acad. Sci., Paris, sêr. D 271, 2186 (1970).

22 A. M. Courgeon, Nature new Biol. 238, 250 (1972).

${ }^{23}$ P. Mandaron, Devel. Biol. 31, 101 (1973).

${ }^{24} \mathrm{~J}$. Benson and H. Oberlander, Insect Biochem. 4, 423 (1974).

25 H. Oberlander, C. E. Leach and C. Tomblin, J. Insect Physiol. 19, 993 (1973).

26 U. Clever, I. Clever, I. Storbeck and N. L. Young, Devel. Biol. 37, 47 (1973).

27 H. Емmerich, Gen. comp. Endocr. 79, 543 (1972).

28 J. Kaplanis, W. Robbins, M. Thompson and S. Dutky, Science 180, 307 (1973).

${ }^{29}$ M. Kambyselits and C. M. Williams, Biol. Bull, 141, 527 (1971).

${ }^{30} \mathrm{~J}$. Benson, H. Oberlander, M. Koreeda and K. Nakanishi, Wilhelm Roux'Arch. 175, 327 (1974).

${ }^{31}$ The authors thank SIMES Laboratories (Milano, Italy) for a gift of ecdysones, Dr. Horfmann for a gift of ${ }^{3} \mathrm{H} \alpha$-ecdysone and Mrs. Goy for expert technical assistance. Supported by grants from CNRS (ATP 'Différentiation Cellulaire' and ATP 'Mécanisme d'action des Hormones') and CEA.

\title{
Radioisotopic Studies of Human Chorionic Gonadotrophin in the Mouse Ovary
}

The ovary of the intact (non-hypophysectomized) mouse has been employed as a target organ to study the physiologic activity of radiolabeled human chorionic gonadotrophin (HCG) ${ }^{1,2}$. The uptake of ${ }^{125} \mathrm{I}$-labeled HCG in the rodent ovary has been described by several investigators ${ }^{3,4}$ including the concentration of labeled HCG in the ovary of hypophysectomized rodents ${ }^{5}$. It was also reported that ${ }^{125}$ I-HCG localizes equally well in mouse theca cell carcinoma of the ovary as in the normal ovary ${ }^{6}$. The importance of such animal model systems has been accentuated by the rapid advancement of the radioligand re- ceptor hormone assays 7,8 . The present study was implemented to further evaluate the tissue localization of ${ }^{125}$ I-labeled $\mathrm{HCG}$ in the mouse ovary. Our findings indicate that ${ }^{125} \mathrm{I}-\mathrm{HCG}$ concentrates consistently in the thecal and interstitial cells, but differentially in the corpus luteum of the intact mouse ovary.

Materials and methods. HCG (Antuitrin-S, $1700 \mathrm{IU} / \mathrm{mg}$ ) was kindly supplied by Dr. Merritt R. Callantine, Parke-Davis, Ann Arbor, Michigan. Human growth hormone $(\mathrm{HCH})$, used as a protein and trophic hormone control for the HCG studies, was provided through the 
The percent dose per gram of tissue $(\% / g)$ is demonstrated for various tissues of radiohormone injected male and female mice

\begin{tabular}{|c|c|c|c|c|c|c|}
\hline \multicolumn{2}{|c|}{ Radiohormone employed } & \multicolumn{5}{|c|}{ Tissues studied } \\
\hline & & Ovary & Testis & Kidney & Liver & Muscle \\
\hline${ }^{125} \mathrm{I}-\mathrm{HCG}$ & $\overline{\mathbf{x}}$ & 15.090 & - & 5.201 & 1.610 & 0.513 \\
\hline (6) & $\mathrm{SE}$ & 3.817 & - & 0.080 & 0.325 & 0.022 \\
\hline 125I-HGH & $\bar{x}$ & 1.082 & - & 3.624 & 1.805 & 0.733 \\
\hline (6) & $\mathrm{SE}$ & 0.215 & - & 0.355 & 0.298 & 0.215 \\
\hline${ }^{125} \mathrm{I}-\mathrm{HCG}$ & $\bar{x}$ & - & 0.175 & 5.910 & 2.490 & 0.476 \\
\hline (4) & $\mathrm{SE}$ & - & 0.025 & 0.104 & 0.035 & 0.037 \\
\hline
\end{tabular}

HGH, human growth hormone; HCG, human chorionic gonadotrophin. The figures represent the mean $(\bar{x})$ and standard error (SEM) of the mean. The number of animals in each study is indicated in parentheses.

courtesy of the Abbott Pharmaceutical Co., North Chicago, Illinois. Both HCG and HGH were labeled with 125I by the method of HunTer and GREenwood ${ }^{9}$. Pooled fractions of ${ }^{125} \mathrm{I}-\mathrm{HCG}$ contained a specific activity of $78.42 \mu \mathrm{Ci} / \mu \mathrm{g}$ and a protein concentration of $3.35 \mu \mathrm{g} / \mathrm{ml}$, while the ${ }^{125} \mathrm{I}-\mathrm{HGH}$ had a specific activity of $86.64 \mu \mathrm{Ci} / \mu \mathrm{g}$ and a protein content of $1.94 \mu \mathrm{g} / \mathrm{ml}$. The radiohormones were suspended in $0.05 M$ phosphate buffer ( $\mathrm{pH} 7.5$ ) stabilized with $1.0 \%$ bovine serum albumin.

The ${ }^{125} \mathrm{I}-\mathrm{HCG}$ was tested for biologic activity by the method of DeLFs ${ }^{10}$; the ${ }^{125}$ I-HGH was assayed by the 10-day body weight test of Evans et al. ${ }^{11}$ The immunologic activity of the ${ }^{125} \mathrm{I}-\mathrm{HCG}$ was evaluated by the method of hemagglutination inhibition as previously described ${ }^{1,12}$. Proof of ${ }^{125}$ I-HCG localization in the mouse ovary was demonstrated by target tissue binding inhibition using rabbit antiserum specific to $\mathrm{HCG}^{\mathbf{1}}$.

Adult female mice of the $A 7(\mathrm{C} 57 \times A)$ strain were employed for the tissue distribution studies. Each of the mice, weighing $20-30 \mathrm{~g}$, received i.v. 30 to $40 \mu \mathrm{Ci}(0.5$ to $1.0 \mu \mathrm{g}$ protein) of ${ }^{125} \mathrm{I}-\mathrm{HCG}$ or ${ }^{125} \mathrm{I}-\mathrm{HGH}$. At $3 \mathrm{~h}$ postinjection, the animals were autopsied and 12 tissue and/or organs were removed, weighed, and assayed for radioactivity in a gamma wellcounter. Results were expressed as the percent dose uptake of isotope per gram of tissue $(\% / g)$. Radioisotopic techniques ${ }^{13}$ were applied to fixed tissue sections of liver and ovary from the ${ }^{125}$ I-HCG and ${ }^{125} \mathrm{HGH}$ treated animals.

Results and discussion. The organ specificity of ${ }^{125} \mathrm{I}-\mathrm{HCG}$ in the ovary of the female mouse was readily demonstrated (Table). The $\% / g$ in the ovary was 15.09 at $3 \mathrm{~h}$ postinjection and 9 to 30 times greater than the concentration of radioiodine in any other tissue studied except the kidney (presumably related to the excretory function of this organ). HGH was not specific for the mouse ovary or any of the other female tissues studied. It is noteworthy that 125 I-HGH is not excreted and/or degraded as rapidly as

1 G. J. Mizejewski, Am. J. Obstet. Gynec. 120, 97 (1974).

2 G. J. Mizejewski, Comp. Biochem. Physiol., in press (1975).

3 A. Eshkol and B. LUnenfeld, in Pharmacology of Hormonal Polypeptides and Proteins (Eds. N. Back, L. Martivi and R. Poolettr; Plenum Press, New York 1968).

4 S. Kammermann and R. E. Canfield, Endocrinology 90, 384 (1972).

5 S. Kazeto and M. Hreshchyshyn, Am. J. Obstet. Gynec. 706, $1229(1970)$

6 G. J. Mize Jewski, Experientia 28, 961 (1972).

7 P. Coulson, I. Tsui-Chu, P. Morris and J. Gorskr, in Gonadotrophins (Eds. B. Saxena, C. G. Beling and H. M. Gandy; Wiley-Interscience, New York 1971), p. 261.

8 H. J. Ranjaniemi, A. N. Hirshfield and A. R. Midgley, jr., Endocrinology 95, 579 (1974).

9 W. M. Hunter and F. C. Greenwoov, Nature, Lond. 194, 495 (1962).

10 E. Delfs, Endocrinology 28, 196 (1941)

11 H. M. Evans and M. S. Simpison, Am. J. Physiol. 98, 511 (1.931).

12 G. J. Mizejewski, W. H. Beierwaltes and J. Quinones, J. nucl. Med. 13, 101 (1972).

13 L. Ii. Appelgren, R. Soremark and S. Ullberg, Biochem. biophys. Acta 66, 144 (1963).

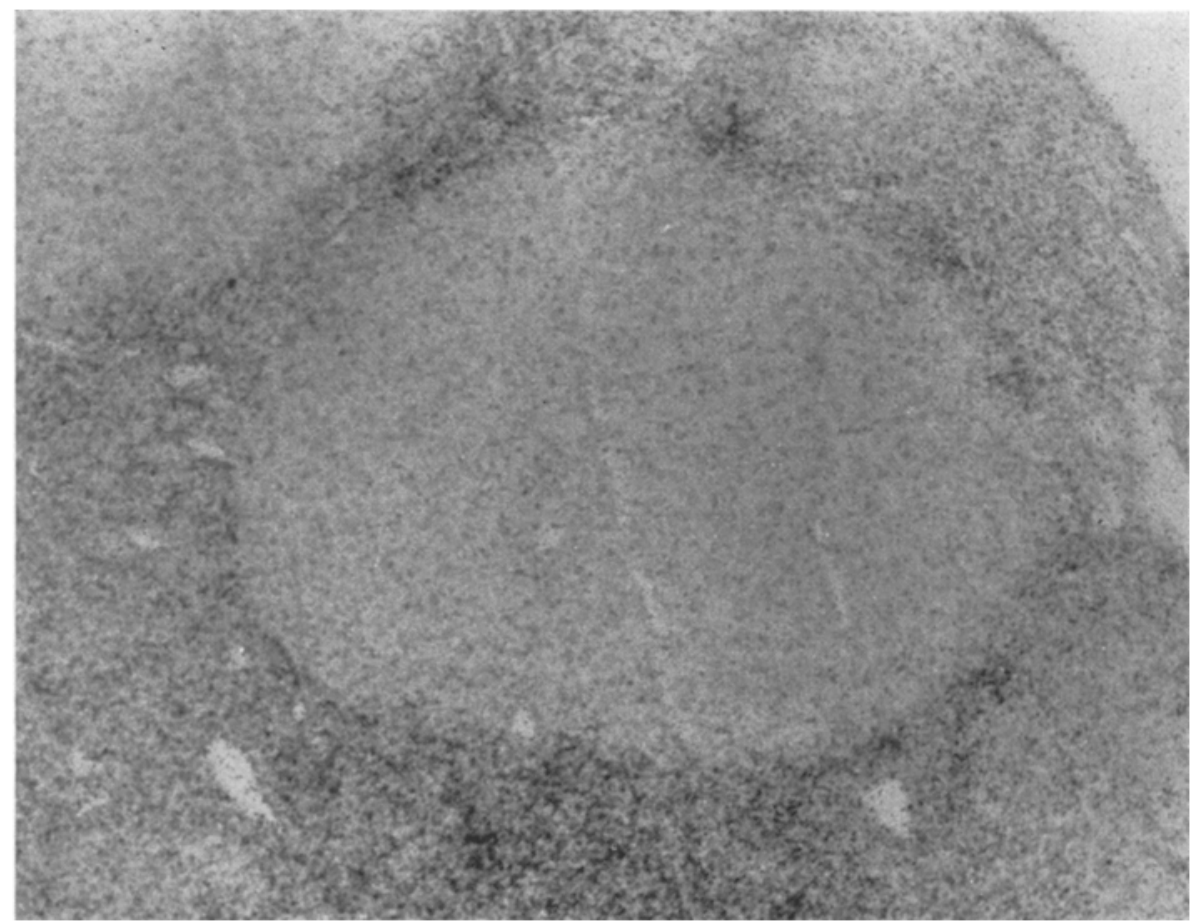

Tissue autoradiogram demonstrating the lack of isotopic localization in the lutein cells of newly-formed corpora lutea. Note the uptake in the interstitium and thecal layers peripheral to thelutea body. $\times 200$. 
the ${ }^{125} \mathrm{I}-\mathrm{HCG}$ in view of the $\% / g$ for the kidneys. A comparable target organ for ${ }^{125} \mathrm{I}-\mathrm{HCG}$ was not found in male mice as evidenced by the $\% / g$ for the testis $(0.17$; see Table). The radioisotopic uptake levels of both hormones were unremarkable in all other tissues.

Autoradiographic analysis revealed the presence of isotopic foci in the thecal and interstitial cells of the mouse ovary in confirmation of previous studies 2,3. Extremely heavy deposits localized in the thecal envelopes but not in the granulosal cells of Graafian follicles. More uniform distributions of radiohormone were apparent among the interstitial cells especially those near developing follicles. Corresponding tissue sections from control animals and from the liver of experimental animals were unremarkable.

As evidenced in the Figure, newly-formed corpora lutea of the intact mouse ovary demonstrated strikingly less isotopic foci than the surrounding theca and interstitium. The lutein cells, which comprised most of the mass of the luteal body, showed little affinity for the ${ }^{125} \mathrm{I}-\mathrm{HCG}$ hormone. In contrast, the luteal bodies bearing signs of atresia showed heavy infiltration of radioisotope distributed throughout the luteal body. Thus, the accumulation of isotopic granules in the corpora lutea appeared to increase as vascularization progressed.

Present studies have demonstrated that ${ }^{125} \mathrm{I}-\mathrm{HCG}$ concentrated in the ovary at $3 \mathrm{~h}$ postinjection. Radioactivity counts in the ovary of intact mice were 9 to 30 times grater than in any other tissue except the kidney. A comparable target organ for ${ }^{125} \mathrm{I}-\mathrm{HCG}$ was not detected in the male including the testis and sex accessory glands. It may be noted that uptake of ${ }^{125}$ I-HCG has only been demonstrated in the rodent testis by tissue silces maintained in vitro ${ }^{14,1}$. ${ }^{125} \mathrm{I}-\mathrm{HGH}$, used as a trophic hormone control, did not concentrate in any of the female organs and tissues.

Isotopic localization of ${ }^{125}$ I-HCG occurred in the thecal and interstitial tissues in juxtaposition to developing follicles. Histologic localization of the radiohormone was less evident in the corpora lutea comprised predominantly of lutein cells. However, heavy deposits of isotope were observed in the atretic or older luteal bodies. Radio-foci were not observed in control tissues and in the livers of mice injected with ${ }^{125} \mathrm{I}-\mathrm{HCG}$.

The differential uptake of ${ }^{125} \mathrm{I}-\mathrm{HCG}$ in the corpora lutea of the intact mouse ovary is of interest from several standpoints. First, in lieu of heavy uptake of ${ }^{125} \mathrm{I}-\mathrm{HCG}$ in the corpora lutea of superovulated and intact rat ovaries, the present results regarding uptake in the mouse is somewhat surprizing, if not, contradictory. Secondly, as a target organ the mouse ovary provides a different model for cell receptor studies involving HCG. Thirdly, additional mechanism of steroid biosynthesis and regulation in the mouse may be implied when comparisons to the rat ovary are made.

The lack of HCG receptivity in the highly luteinized corpora lutea of the mouse may be explained in terms of corpora luteal development. The lutein cells of the mouse are derived almost exclusively from the granulosa cell population ${ }^{15}$. The cells of the granulosal layer did not display an affinity for ${ }^{125}$ I-labeled $\mathrm{HCG}^{2}$; thus, the newlyformed luteal body is populated by cells whose predecessors did not localize HCG to any great extent. However, the thecal cells, which showed a great avidity for ${ }^{125} \mathrm{I}-\mathrm{HCG}$ did not immediately infiltrate the corpus luteum and remain situated on the periphery as shown in the Figure. As the luteal body ages toward atresia, the thecal-derived cells infiltrated the mass of the luteal body and came to line the blood spaces and sinuses therein ${ }^{15,16}$. The thecalderived cells of the corpus lutea retained their avid receptivity for HCG resulting in increased localization in the aging corpus lutea. Thus, the concentration of ${ }^{125} \mathrm{I}-$ HCG in the intact mouse luteal body was dependent on the 1 , vascularization, 2 , age, and 3 , cell distribution in the luteal body.

Summary. The tissue localization of ${ }^{125} \mathrm{I}-\mathrm{HCG}$ was studied in intact mice. ${ }^{125} \mathrm{I}-\mathrm{HCG}$ concentrated in the thecal and interstitial tissues of the ovary. Differential uptake occurred in the corpora lutea which was dependent on the age and vascularization of the luteal body.

\section{G. J. MızeJEwSKI ${ }^{17}$}

Veterans Administration Hospital,

University of Michigan Medial Cenier,

Ann Arbor (Michigan, USA), 10 June 1975.

14 D. M. De Kretser, K. J. Catt and C. A. Paulsen, Endocrinology $88,332(1971)$.

${ }^{15}$ F. W. R. Brambell in Physiology of Reproduction (Ed. A. S. Parkes; Longrans, Green, \& Co., New York 1956), vol. 1, chapt. 5, p. 397.

16 D. L. Bassetr, Am. J. Anat. 73, 251 (1943).

17 Present address: Division of Laboratories \& Research, New York State Dept. of Health, Albany, New York 12201, USA.

\section{PRO EXPERIMENTIS}

\section{A Simple Method of Preparing a Cell Suspension for Scanning Electron Microscopy}

As part of a study on the behaviour of cell suspensions, it was decided to investigate the surface topography of 7-day neural retina cells with the scanning electron microscope ${ }^{\mathbf{1}}$. For the sake of direct comparison with other investigative techniques it was most important that the cells were prepared from a monodispersed cell suspension.

Cell preparations have been obtained for scanning electron microscopy (SEM) by many methods ", involving either plating out prior to critical point drying (CPD) ${ }^{3}$, air drying ${ }^{4}$ freeze drying ${ }^{5}$ or spray freezing ${ }^{6}, 7$ from suspension.

The few methods described for handling cell suspensions for CPD were not suited to our needs for reasons discussed later. We, therefore, devised a versatile method for the processing of suspended cells for SEM, which ensures excellent preservation of surface structure and allows for comparisons with other data on cell suspensions.
Materials and methods. Neural retina cells from 7-day chick embryos were disaggregated following a previously described technique ${ }^{8}$. The cell suspension was spun at $300 \mathrm{~g}$ for $5 \mathrm{~min}$, the supernatant discarded, and the cell

${ }^{1}$ G. E. Jones, J. Cell Sci. 17, 371 (1975).

2 K. R. Porter, D. Kelley and P. M. Andrews, Proc. of the 5 th annual Stereoscan Scanning Electron Microscope Colloquium. Kent Cambridge Scientific, Inc., Morton Grove, ILL. (1972).

${ }^{3}$ L. P. Everhart JR, and R. W. Rubin, J. Cell Biol, 60, 442 (1974).

${ }^{4}$ I. Carr, J. A. Clarke and A. J. Salisbury, J. Microsc. 89, 105 (1969).

5 R. A. Hammond, J. Microse. 90, 273 \{1969\}.

${ }^{B}$ L. Bachmann and W. W. Schmitt, Proc. natn. Acad. Sci., USA 68,2149 (1971).

7 H. Platiner, W. M. Fischer, W. W. Schmitt and L. Bachmann, J. Cell Biol. 53,116 (1972). 